\title{
TECHNOLOGY AND COMMUNICATION IN HOSPITAL CARE FOR CHRONICALLY ILL PATIENTS FROM THE HABERMASIAN PERSPECTIVE
}

\author{
Manuel Rich-Ruiz', Maria-Manuela Martins², María-Aurora Rodríguez-Borrego ${ }^{3}$
}

\footnotetext{
${ }^{1}$ Ph.D. from the Universidad de Cordoba. Professor at the Nursing Department of the Universidad de Cordoba. Cordoba, Spain. Email: mrich@uco.es

2 Ph.D. in Nursing. Professor at the Escuela Superior de Enfermería. Porto, Portugal. Email: mmartins@esenf.pt

${ }^{3} \mathrm{Ph}$.D. from the Universidad de Valladolid. Professor at the Department of Nursing of the Universidad de Cordoba. Cordoba, Spain. Email: en1robom@uco.es
}

\begin{abstract}
The objectives of the study were to describe situations involving instrumental and communicative actions that take place in nursing and to explore the difficulties in communicative action. It was an ethnographic study conducted among nurses from two large hospitals in Spain and Portugal. Data collection took place through participant observation and semi-structured interviews. It was then followed up by a survey. A discourse analysis and quantitative analysis were performed (on the survey). The nurses' work consisted mainly of instrumental actions. Among the social actions, those of a strategic type predominate, whereas communicative actions are scarce and non-specific. It was noted that difficulties in communicative actions were linked to "New Management" and "Encoded Knowledge". Nursing requires a more balanced distribution between the time dedicated to technology and communication. The difficulties involved in communicative action appear to coincide with Habermasian systems, although renewed forms are adopted. DESCRIPTORS: Professional practice. Philosophy in nursing. Professional-patient relations. Communication. Knowledge, attitudes and practices in health.
\end{abstract}

\section{TECNOLOGÍA Y COMUNICACIÓN EN EL CUIDADO HOSPITALARIO A ENFERMOS CRÓNICOS DESDE LA PERSPECTIVA DE HABERMAS}

RESUMEN: Los objetivos del estudio fueron: describir las situaciones de acción instrumental y comunicativa que ocurren en la práctica enfermera y explorar las dificultades para la acción comunicativa. Estudio etnográfico realizado con enfermeras de dos grandes hospitales de España y Portugal. La recogida de datos se llevó a cabo a través de observación participante y entrevistas semiestructuradas. Posteriormente, se completó con una encuesta. Se realizó análisis del discurso y análisis cuantitativo (de la encuesta). El trabajo de las enfermeras consta, básicamente, de acciones instrumentales. Entre las acciones sociales, predominan las de tipo estratégico, siendo las acciones comunicativas escasas e inespecíficas. Se han identificado dificultades para la acción comunicativa asociadas a la "Nueva Gestión" y al "Conocimiento Codificado". La práctica enfermera demanda un reparto más equilibrado entre los tiempos dedicados a la tecnología y la comunicación. Las dificultades para la acción comunicativa parecen coincidir con los sistemas habermasianos, aunque adoptando formas renovadas.

DESCRIPTORES: Práctica profesional. Filosofía en enfermería. Relaciones profesional-paciente. Comunicación. Conocimientos, actitudes y práctica en salud.

\section{TECNOLOGIA E COMUNICAÇÃO NO CUIDADO HOSPITALAR AO DOENTE CRÔNICO NA PERSPECTIVA DE HABERMAS}

\begin{abstract}
RESUMO: Os objetivos do estudo foram: descrever as situações de ação instrumental e comunicativa que acontecem na prática de enfermagem e explorar as dificuldades para a ação comunicativa. Estudo etnográfico levado a cabo com enfermeiros de dois grandes hospitais da Espanha e de Portugal. A coleta de dados foi realizada por meio de observação participante e entrevistas semiestructuradas. Posteriormente, a coleta foi completada com uma enquete. Utilizou-se análise do discurso e análise quantitativa (da enquete). O trabalho dos enfermeiros consiste, basicamente, de ações instrumentais. Entre as ações sociais, prevalecem as ações de tipo estratégico, sendo as ações comunicativas escassas e inespecíficas. Foram identificadas dificuldades, para a ação comunicativa, associadas à "Nova gestão" e ao "Conhecimento Codificado". A prática de enfermagem exige uma distribuição mais equilibrada entre os tempos dedicados à tecnologia e à comunicação. As dificuldades para a ação comunicativa parecem coincidir com os sistemas habermasianos, embora adotando formas renovadas.
\end{abstract}

DESCRITORES: Prática profissional. Filosofia em enfermagem. Relações profissional-paciente. Comunicação. Conhecimentos, atitudes e prática em saúde. 


\section{INTRODUCTION}

Many people are expressing concern about the excessively technical nature and empiricism of the current healthcare systems. ${ }^{1}$ The presence of instrumental values has increased so much that some authors view this situation as a serious threat to personalized care ${ }^{2}$ and, in turn, to nursing. ${ }^{3-4}$

This paper, however, seeks to downplay alarmism and build on the basis of more optimistic premises, in the belief that it is possible to unite technology and humanized care in "a technologically advanced system characterized not by dehumanization and despair, but by brightness, hope and life" .5:17

Based on this conviction, the study uses the Theory of Communicative Action (TCA) by Jürgen Habermas ${ }^{6}$ because his idea that society is structured concurrently on two levels (lifeworld and system - Habermas' most original insight, according to some authors) $)^{7}$ enables to explain nursing practice as both a particular and systemic reality, where humanized care and technology fit neatly together.

Another idea of Habermas, the colonization of the lifeworld by the system, also makes the Habermasian framework a framework equally useful to explain the excessively technical nature and empiricism of current health systems, resulting from, according to Habermas, a certain modernization process, the process of capitalist modernization, which has pathologically systematized many ordinary situations. ${ }^{6}$

The colonization of the lifeworld by the system is characterized by the high frequency of instrumental actions (technical, non-social actions) and strategic actions (social actions in which the speaker only transmits information or influences the listener) in the realms of communicative action; therefore it is possible to deduce the degree of colonization of health systems by observing the frequency of these actions ${ }^{6}$ in situations involving communicative action.

However, it should be noted that we do not consider the colonization of the lifeworld to be a general or homogeneous problem. Previous studies have found that patients do not always seek communicative action. The need for communicative action on the part of patients is closely related to the clinical problem, where it is greater in the case of psychological disorders or when there is a clear experiential component, such as with psychiatric, oncohematologic or chronic illnesses, than in the case of acute conditions, ${ }^{8}$ where the patient expects a unilateral, expert answer from the professional which does not involve dialogue.

Therefore, lack of communicative action does necessarily denote a problem in acute patient care. Likewise, this does not appear to be the case in the care of psychiatric or oncohematologic patients, who tend to easily obtain a response to their demands for communicative attention. Chronic patients are the ones whose care is still governed by the biological component, who feel a disruption on an experiential level ${ }^{9-11}$ and do not receive clear answers from professionals. This is the reason why our study focused on this type of patient.

The objectives of this study were: 1) Describe the instrumental actions that nurses perform during the hospitalization of chronically ill/long-term patients; 2) Identify the communicative action situations that arise during the care of chronically ill/ long-term patients in the hospital; and 3) Explore, where applicable, the difficulties involving communicative action in practice.

\section{METHODS}

This is an ethnographic study conducted among nurses from two large hospitals with over 1,000 beds. One was located in the south of Spain and the other in the north of Portugal. Both are considered to be high technology hospitals.

One unit was studied in Spain and two in Portugal, all dedicated to caring for chronically ill or long-term patients. A theoretical sampling was performed. The units were chosen based on the assessment of nursing managers that these units provide quality care. The results, therefore, are linked to best practices.

Using the same criteria, quality care defined by the nursing managers, the nurses responsible for managing the units were requested to provide names of possible participants. Temporary staff was avoided in an effort to use professionals with extensive experience in caring for this type of patient.

A period of participant observation was performed in each of the hospitals. The participant observation in Spain took place during the month of June, 2011. In Portugal, it was conducted during the months of July and August, 2011. The observation was daily and intensive, until the research team deemed it had the necessary elements to build a comprehensive and convincing framework for the issue. At the end of each observation periods, 
semi-structured interviews were arranged. Four interviews were conducted in the Spanish hospital and six in the Portuguese hospital. The number of interviews was determined by the saturation of the discourse in its central aspects. Lastly, a survey was conducted among the entire population of the units that were studied. The response rates obtained were $92.8 \%, 68.6 \%$ and $100 \%$, corresponding to a total of 112 participants. This survey contained examples of instrumental, strategic and communicative situations (Table 1) that needed to be applied to three realms: the realm of thought, action and doing records. The instrument was validated in an earlier stage of the project by the research team. For this purpose, experts were consulted and a test pilot was performed. To test its reliability a Cronbach a test was done. All the items obtained values close to and greater than 0.8 .

However, the design takes participant observation, and therefore the understanding of the discourse shared by the professional groups, as the primary source of explanation.

\section{Table 1 - Actions included in the survey}

\begin{tabular}{|c|c|c|c|c|c|c|}
\hline \multicolumn{7}{|c|}{ I think... is important } \\
\hline 1 & When a patient arrives, talk with him or her (to take into account their particular needs). & 1 & 2 & 3 & 4 & 5 \\
\hline 2 & Administer the prescribed treatment. & 1 & 2 & 3 & 4 & 5 \\
\hline 3 & Pay attention to the preparation required for each diagnostic test (radiology, laboratory, etc.). & 1 & 2 & 3 & 4 & 5 \\
\hline 4 & $\begin{array}{l}\text { Know all that needs to be done with each patient (tests and treatments) and check that it has } \\
\text { been done. }\end{array}$ & 1 & 2 & 3 & 4 & 5 \\
\hline 5 & Monitor vital signs and other measures (drainage, etc.). & 1 & 2 & 3 & 4 & 5 \\
\hline 6 & Be mindful of the emotional state of each patient. & 1 & 2 & 3 & 4 & 5 \\
\hline 7 & $\begin{array}{l}\text { Process all requests from physicians for tests and treatments (according to the rules estab- } \\
\text { lished by the institution). }\end{array}$ & 1 & 2 & 3 & 4 & 5 \\
\hline 8 & $\begin{array}{l}\text { Know each patient's ability to perform daily activities (bathing, getting dressed, feeding, go- } \\
\text { ing to the toilet...). }\end{array}$ & 1 & 2 & 3 & 4 & 5 \\
\hline 9 & $\begin{array}{l}\text { Know about the patient's daily life outside the hospital (environment, social networks, hab- } \\
\text { its, customs, etc.). }\end{array}$ & 1 & 2 & 3 & 4 & 5 \\
\hline 10 & Do not forget any medical prescription. & 1 & 2 & 3 & 4 & 5 \\
\hline 11 & $\begin{array}{l}\text { Every time I go in the room, start up a conversation (so that the patient will tell me what he/ } \\
\text { she needs). }\end{array}$ & 1 & 2 & 3 & 4 & 5 \\
\hline 12 & Meet the objectives of the unit/service. & 1 & 2 & 3 & 4 & 5 \\
\hline 13 & At certain times (surgery the next day, a setback, etc.), spend time with the patient. & 1 & 2 & 3 & 4 & 5 \\
\hline 14 & Convince the patient to follow the prescribed treatment. & 1 & 2 & 3 & 4 & 5 \\
\hline 15 & $\begin{array}{l}\text { When a patient is nervous, anxious, distressed or discouraged, administer a medication or } \\
\text { notify the physician to work out the problem. }\end{array}$ & 1 & 2 & 3 & 4 & 5 \\
\hline 16 & $\begin{array}{l}\text { Know how the patient views his or her illness, the tests being done or the treatments being } \\
\text { given. }\end{array}$ & 1 & 2 & 3 & 4 & 5 \\
\hline 17 & $\begin{array}{l}\text { In cases where the illness radically changes the person's life, help the patient integrate the } \\
\text { new situation into his or her daily life. }\end{array}$ & 1 & 2 & 3 & 4 & 5 \\
\hline 18 & $\begin{array}{l}\text { Provide help, as needed, so that the patient can obtain more specialized care (nutritionist, } \\
\text { physical therapist, psychologist, social worker, etc.). }\end{array}$ & 1 & 2 & 3 & 4 & 5 \\
\hline \multicolumn{7}{|c|}{ When I do (in my day-to-day)...it is important } \\
\hline \multicolumn{7}{|c|}{ The same actions are repeated } \\
\hline \multicolumn{7}{|c|}{ When I do records... it is important to collect } \\
\hline \multicolumn{7}{|c|}{ The same actions are repeated } \\
\hline
\end{tabular}

For analyzing the information, a content analysis was performed. In this analysis, the previously built theoretical framework and possible emerging categories were taken into consideration. The software used was the program Weft QDA.
The content analysis was later enriched with an analysis of the context in which the discourses arose, with a detailed description of the circumstances under which they were produced; as well as a sociological analysis establishing connections 
between the discourses analyzed and the social space in which they emerged, focusing attention on the particular viewpoint of the subject as an indication of ideological constructs.

To describe the actions included in the survey, means were calculated; and to confirm the existence of difficulties in communicative action, a comparison of means for paired data was performed.

A triangulation of methods (observation, semi-structured interviews and survey) was used with the subjects (by contrasting and negotiating meanings with the participants) and researchers (by incorporating two outside experts, with whom reflective dialogues were established to deepen the analysis, reformulate problems and build new ideas).

The development of the study was approved by an Ethics Committee. Permission was requested from the different centers and a verbal and written informed consent form was obtained from the participants. The anonymity of the participants, as well as the confidentiality of the information, was ensured.

\section{RESULTS}

\section{Description of the participants}

The participants in the Spanish hospital belonged to a medical specialty unit. The unit comprised mostly women, 30 years of age or older (mean age: 46.93), with extensive experience in caring for chronically ill patients with respiratory diseases.

In relation to the participants from the Portuguese hospital, the first unit studied was mostly made of young people, 35 years of age or younger (mean age: 31.95 ); female (only a $22.1 \%$ of men), and limited professional experience $(57.3 \%$ with less than five years). According to the participants, "[internal] medicine is very difficult and the older nurses do not like it (PN1)". The characteristics of the professionals from the second unit studied in Portugal were very similar, although the predominant age range in this case was higher, from 30-40 years (mean age: 36.36 ).

The references, descriptors and subjects used in the content analysis are presented in table 2.

\section{Table 2 - Content analysis: subjects, descriptors and reference examples}

\begin{tabular}{|c|c|c|}
\hline Subjects & Descriptors & References \\
\hline $\begin{array}{l}\text { Non-social/instrumen- } \\
\text { tal actions }\end{array}$ & $\begin{array}{l}\text { Prescriptions } \\
\text { Administrative work } \\
\text { Physical care }\end{array}$ & $\begin{array}{l}\text { We have medication schedules at } 9 \text { am and noon [...]. In terms } \\
\text { of position changes, we have a protocol where changes are } \\
\text { performed every two and half to three hours more or less [...] } \\
\text { (PN6). }\end{array}$ \\
\hline \multirow[t]{5}{*}{ Social actions } & \multirow[t]{2}{*}{$\begin{array}{l}\text { Lack of time: difficulties in find- } \\
\text { ing time for communicative ac- } \\
\text { tions }\end{array}$} & $\begin{array}{l}\text { Times for communication exist if you look for them. If you } \\
\text { aren't looking for them, you can get by without them, because } \\
\text { you can then simply dedicate yourself to your duties and noth- } \\
\text { ing more (SN1). }\end{array}$ \\
\hline & & $\begin{array}{l}\text { Unfortunately we don't have time to indulge in conversation } \\
\text { with patients (PN2). }\end{array}$ \\
\hline & $\begin{array}{l}\text { Informational-educational ac- } \\
\text { tions as manifestations of social } \\
\text { action }\end{array}$ & $\begin{array}{l}\text { [We] teach a little about everything [to patients or family } \\
\text { members], so that when they're discharged and continue to } \\
\text { be dependent, they can take care of themselves at home (PN2). }\end{array}$ \\
\hline & $\begin{array}{l}\text { Systematization: communica- } \\
\text { tion as a disruption to the work } \\
\text { pace }\end{array}$ & $\begin{array}{l}\text { It's not intentional. It's just that my priority at the time is to } \\
\text { give medication [...] if I stop with each patient, perhaps I'll } \\
\text { give the last medication at } 11 \text { in the morning when I should } \\
\text { have given it at 9:00 (SN2). }\end{array}$ \\
\hline & $\begin{array}{l}\text { Communicative actions are ig- } \\
\text { nored and even blocked out }\end{array}$ & $\begin{array}{l}\text { [...] so many times you get the 'hey!, I was waiting for you' and } \\
\text { 'I was waiting for you' it's work, work, work [...] that's one } \\
\text { of the reasons why I don't ask 'how are you doing' [laughs] } \\
\text { (SN1). }\end{array}$ \\
\hline Economic system & $\begin{array}{l}\text { Clinical management systems } \\
\text { Bureaucratic control systems } \\
\text { Economic incentives }\end{array}$ & $\begin{array}{l}\text { [...] since I've been in a lot of places, eight months going here } \\
\text { and there [referring to a period of time when the person } \\
\text { was doing substitution work] I used to say: there's a lot of } \\
\text { desk work here, but no one does the front-line work. And when } \\
\text { the new shift would arrive there'd be all these crummy situa- } \\
\text { tions. Sure, lots of goals were set, but as far as work, no one } \\
\text { really works (SN3). }\end{array}$ \\
\hline
\end{tabular}




\begin{tabular}{|l|l|l|}
\hline Bureaucratic system & $\begin{array}{l}\text { Social sacralization of science } \\
\text { Instrumental professional so- } \\
\text { cialization } \\
\text { Evidence-based practice } \\
\text { Methodological tradition }\end{array}$ & $\begin{array}{l}\text { When a patient comes here [to the hospital] all these [naso- } \\
\text { gastric] catheter insertion techniques must be performed [...] } \\
\text { we do it for the sake of the patient, regardless of the family's } \\
\text { consent, because it's something the patient needs at that time } \\
\text { (PN3). }\end{array}$ \\
\hline
\end{tabular}

\section{Description of instrumental actions}

The nurses' work in both hospitals basically entails administration of medication and other therapies, performing diagnostic tests and monitoring vital signs. Doing this takes up most of the patient care time. Along with these activities, in the second hospital (northern Portugal), the physical care of dependent patients also has a prominent place (food, hygiene, self-image care, position changes) - activities that in the Spanish hospital were delegated to nursing assistants.

In addition, the nurses in both places did an enormous amount of administrative work. In the case of the Spanish nurses, it is clearly larger. The Spanish nurses are responsible for admission of patients, processing of diagnostic tests, specialist consultation sheets, diet requests, communication with the pharmacy, ambulance management, etc., all in the midst of their clinical work.

\section{Communicative action situations}

As it might be expected, in this systematic, even automatic, work environment, with its frenetic pace, nurses mention that it is difficult to find time for communication. Communication mainly occurs when nurses go to the patient's room to perform one of the many scheduled instrumental (or technical) actions, at which time they engage in strategic actions of an informational-educational nature. Apart from these informational-educational actions, the nurses view communication as an interruption to their systematic work pace and therefore ignore, or even block out patients' questions and communication in general.

Nevertheless, episodes of communicative action can be noted in to the second setting (northern Portugal). The nurses take advantage of basic care to engage in communicative dialogue with patients about day-to-day things: the angle of the chair, how long they remain seated, temperature of the food, eating frequency, taking showers or getting washed up in bed.

In relation to the results of the quantitative analysis, one also notes the predominance of instrumental and strategic actions in the realm of action (Table 1). However, the instrument appears to lead to high scores in all cases, despite the measures taken to ensure the confidentiality of the responses.

Table 1 - Descriptive analysis of the instrumental, communicative and strategic actions included in the survey. Spain/Portugal 2011

\begin{tabular}{|c|c|c|}
\hline Thought & Action & Record \\
\hline $4,87(\mathrm{~A} 1)^{*}$ & 4,63 (A2) & 4,61 (A2) \\
\hline 4,66 (A2) & 4,58 (A10) & 4,61 (A10) \\
\hline 4,60 (A8) & 4,57 (A5) & 4,58 (A5) \\
\hline $4,57(\mathrm{~A} 4)$ & 4,53 (A1) & 4,46 (A4) \\
\hline 4,50 (A6) & 4,50 (A3) & 4,44 (A7) \\
\hline 4,49 (A17) & 4,48 (A4) & 4,36 (A8) \\
\hline 4,47 (A10) & 4,46 (A8) & 4,36 (A15) \\
\hline 4,46 (A5) & 4,40 (A18) & 4,35 (A3) \\
\hline 4,44 (A3) & 4,39 (A7) & 4,28 (A18) \\
\hline 4,43 (A13) & 4,38 (A6) & 4,23 (A6) \\
\hline 4,37 (A11) & 4,37 (A17) & 4,22 (A9) \\
\hline 4,35(A18) & 4,35 (A11) & 4,19 (A1) \\
\hline 4,32 (A15) & 4,33 (A15) & 4,15 (A14) \\
\hline 4,29 (A16) & 4,28 (A13) & 4,14 (A16) \\
\hline 4,28 (A14) & 4,23 (A16) & 4,13 (A17) \\
\hline 4,18 (A7) & 4,09 (A14) & 3,98 (A13) \\
\hline 4,09 (A9) & 4,05 (A12) & 3,96 (A12) \\
\hline 4,09 (A12) & 4,04 (A9) & 3,96 (A11) \\
\hline
\end{tabular}

* mean (number of action as it appears in table 1).

Color code of Table 1

\begin{tabular}{l}
\hline Instrumental actions \\
\hline Communicative actions \\
\hline Strategic actions \\
\hline
\end{tabular}

Regarding the existence of difficulties in communicative action, detected in the discourse, it can also be argued quantitatively if taking into account a comparison of means for paired data from the communicative actions group, with significant differences in the scores given to these actions in the realm of thought in relation to action and records $(p=0.003$ and $p=0.00$ respectively). 


\section{Difficulties in communicative action}

With respect to the reasons that hinder communication, they are related to the context in which nursing is practiced nowadays. If one looks beyond the argument of lack of time in order to detect hidden elements behind this reason, two key elements in this situation can be noted: monetization, the economic system; and bureaucratization, the bureaucratic system - the two Habermasian systems that usually invade or colonize the lifeworld.

The nurses feel that health systems have introduced a business culture and tools - New Management - where mercantilist/economic criterias outweigh traditional humanistic values. Furthermore, in the Spanish hospital, the existing bureaucratic control systems to ensure the efficiency have generated such bureaucratic activity that it has upset the balance between clinical and bureaucratic activities in favor of the second. Nurses have stopped watching patients and are instead looking at computer screens.

As far as the difficulties associated with the bureaucratic subsystem, they are less visible. The nurses consider treatment as an obligation that patients must accept sine qua non. Patients come to be treated. This perspective does not create any discrepancy because this view is largely shared by patients and family members. In light of the frequent explanations of nurses (evidencebased), it was unusual to note challenges to the established scientific order by patients or family members.

\section{DISCUSSION}

The results are consistent with previous studies that describe nursing as being characterized by the administration of medication and other therapies, the performing of diagnostic tests, monitoring vital signs and paperwork and other administrative tasks. ${ }^{12-13}$ Other studies mention the high volume of work related to these tasks ${ }^{14}$ and the sensation of lack of time developed in the nurses. ${ }^{12}$ And last, it is not difficult to find references to the sacrificing nurse-patient interaction resulting from the need to perform other tasks away from patients. ${ }^{15}$

It might seem, therefore, that the situation has been sufficiently studied. However, to explain the lack of communicative action as a result of instrumental actions and their frequency would be to simplify the problem. In fact, the literature consulted provides other answers similar to the results of this study: monetization and bureaucratization. ${ }^{16}$

Regarding monetization, it is odd to accuse money of invading the space that communication should occupy in a health systems where, if something happens is that, people are demanding more than they really need. Obviously, money is not a bargaining chip in terms of conversations with patients, but it does substantially pressure our health systems, which have introduced a business culture and tools - New Management where mercantilist criteria outweigh traditional humanistic values. ${ }^{17}$

With respect to bureaucratization, this study shows how patients continue having to adapt to rigid and oppressive health structures which even the professionals are not able to fight against. It also finds situations where professionals use power strategically. But "professionals were already arrogant and hospital policies were already rigid 30 years ago [...]. If dehumanization is a more serious problem nowadays it must be due to the action of a different mechanism". 16:290

The results of the study indicate that Encoded Knowledge - a continuous effort to formalize everything on the basis of evidence - could be a possible mechanism that is giving rise to the exclusion of the patient in the care process. EvidenceBased Practice advocates the need to include the patient in decision-making. However, the fact is that this trend has led to the supremacy of universal criteria derived from science - in capital letters - over the particular criteria derived from practice. ${ }^{18-19}$

Moreover, this situation is especially critical in the case of nursing, since in its culture: "there is virtually no room for implicit thought, because the nursing discipline is basically methodological and in its praxis is accustomed to working in a disciplined manner, in obedience to orders, protocols and care plans" ${ }^{19: 25}$

The results of this study could contribute to a new understanding of nursing, where the strong systems into which it is inserted are taken into account.

Politicians and institutions would need to listen to the demands of nurses to carry smaller loads and be freed from certain tasks, for instance, to enable them to attend to the health-illness experiences of individuals. 
The results raise important questions and doubts about the possibility of providing care that focuses on health-illness experiences and that is warm, humanized and personal, given the excessive trust placed by patients, and especially by professionals, in indifferent, cold, classical science. ${ }^{5,20}$ The academic world should take this into account and include specific training on communicative rationality within its curricula.

In any case, the results indicate that the proposed framework (TCA) is an appropriate perspective for the field of nursing, as well as a promising paradigm for research and development of the discipline..$^{21-22}$

\section{CONCLUSIONS}

In the final analysis, the results of the study clearly indicate a practice characterized by technical and instrumental actions with little opportunity for communicative action and humanization. The circumstances that contribute to this coincide with the reasons for the colonization of the lifeworld proposed by Habermas, that is, the constraints of the economy (money) and bureaucracy (power).

However, the findings of this study are subject to several limitations. On the one hand, the participants were only part of the entire group of professionals working in the different units. Furthermore, the existence of pressure in terms of time limited the depth of the study. Finally, it should be pointed out that the perspectives offered are related to specific health systems, at a given point in time, subject to the internal and external social influences of the moment.

\section{REFERENCES}

1. Svenaeus F. Medical technologies and the life world: an introduction to the theme. Med Health Care and Philos. 2009; 12 (2):121-3.

2. Walseth LT, Schei E. Effecting change through dialogue: Habermas' theory of communicative action as a tool in medical lifestyle interventions. Med Health Care and Philos. 2011; 14: 81-90.

3. Sellman D. Professional values and nursing. Med Health Care and Philos. 2011; 14: 203-8.

4. O'Keefe-McCarthy S. Technologically-mediated nursing care: the impact on moral agency. Nurs Ethics. 2009; 16(6):786-96.

5. Dossey L. Tiempo, espacio y medicina. Barcelona (ES): Editorial Kairós; 2006.
6. Habermas J. Teoría de la acción comunicativa. Madrid (ES): Editorial Taurus; 1992.

7. Noguera JA. La teoría crítica: de Frankfurt a Habermas. Una traducción de la teoría de la acción comunicativa a la sociología. Papers. 1996; 50: 133 53.

8. Barry CA, Stevenson FA, Britten N, Barber N, Bradley CP. Giving voice to the lifeworld. More humane, more effective medical care? A qualitative study of doctor-patient communication in general practice. Soc Sci Med. 2001; 53(4):487-505.

9. Delbene R. Patients' narratives of chronic illnesses and the notion of biographical disruption. Commun Med. 2011; 8(1):17-27.

10. Larsson AT1, Grassman EJ. Bodily changes among people living with physical impairments and chronic illnesses: biographical disruption or normal illness? Sociol Health Illn. 2012; 34(8):1156-69.

11. McMurray A, Chaboyer W, Wallis M, Johnson J, Gehrke T. Patients' perspectives of bedside nursing handover. Collegian. 2011; 18(1):19-26.

12. Andrews DR, Burr J, Bushy A. Nurses' Self-concept and perceived quality of care. A narrative analysis. J Nurs Care Qual. 2011; 26(1):69-77.

13. Pearce C, Phillips C, Hall S, Sibbald B, Porritt J, Yates $\mathrm{R}$, et al. Contributions from the lifeworld: quality, caring and the general practice nurse. Qual Prim Care. 2009; 17: 5-13.

14. Westbrook JI, Duffield C, Li L, Creswick NJ. How much time do nurses have for patients? A longitudinal study quantifying hospital nurses' patterns of task time distribution and interactions with health professionals. BMC Health Serv Res. 2011; 11: 319.

15. Carvalho B, Peduzzi M, Mandú EN, Ayres JR. Work and Inter-subjectivity: a theoretical reflection on its dialectics in the field of health and nursing. Rev Latino-Am Enfermagem. 2012; 20(1):19-26.

16. Fredriksen $S$. Instrumental colonization in modern medicine. Med Health Care and Philos. 2003; 6: 287-96.

17. Propper C. Competition, incentives and the English NHS. Health Econ. 2012; 21(1):33-40.

18. Ferlie E1, McGivern G, Fitzgerald L. A new mode of organizing in health care? Governmentality and managed networks in cancer services in England. Soc Sci Med. 2012; 74(3):340-7.

19. Hernández Yañez JF. La enfermería frente al espejo: mitos y realidades. Madrid (ES): F. Alternativas; 2010 .

20. Sunvisson H1, Habermann B, Weiss S, Benner P. Augmenting the cartesian medical discourse with an understanding of the person's lifeworld, lived body, life story and social identity. Nurs Philos. 2009; 10(4):241-52. 
21. Ramos FRS, Bertoncini JH, Machado RR, Flor RC, Pires DE, Gelbcke FL. Trabalho, educação e política em seus nexos na produção bibliográfica sobre o cuidado. Texto Contexto Enferm. 2009 Abr-Jun;
18(2):361-8.

22. Sumner J. A critical lens on the instrumentation of caring in nursing theory. ANS Adv Nurs Sci. 2010; 33(1):E17-26.

E-mail: mrich@uco.es 